\title{
The impacts of new technologies on urban transformations
}

\author{
A. Katsara \\ Department of Planning and Regional Development, \\ University of Thessaly, Volos, Greece
}

\begin{abstract}
This paper concerns the impacts of new technologies on urban morphology, structure and landscape. More specifically, it investigates two aspects of impacts: (a) the change of urban morphology in contemporary cities by means of computer-aided architectural design and construction techniques, and (b) the shift of the spatial core and the expansion of the CBD in the post-industrial cities by means of the emerging new clusters of technology intensive and knowledge based firms in inner city areas. The research documents these impacts of new technologies by illustrating examples of metropolitan cities located in both the economic core and the periphery of Europe, such as Milan, Barcelona and Athens.

Keywords: new technologies, urban morphology, urban landscape, computeraided architectural design and construction techniques, clusters of technologyintensive and knowledge-based firms.
\end{abstract}

\section{Introduction}

Major changes in the economic activity of post-industrial cities under the conditions of economic globalisation, technological developments in the new sectors of information and communication and the rapid growth of transportation and communications networks, influence the spatial, social and economic structure of cities. Urban space gets restructured through the changes of economic reformation of cities and in the new patterns of social life of people. All over the world, metropolitan and large cities make efforts to re-define place and their identity. They also make efforts to reinforce their status in the global 
urban hierarchies, to give impulse in their economic development and attract investments and visitors.

Architecture, urban planning, urbanism, and in general all disciplines related to urban space, appear to face great challenges.

This paper attempts to investigate the transformations of urban landscapes related to two aspects. First, transformations caused by innovative architectural and urban design, produced by computer-aided techniques in both design and construction. Second, transformation caused by the concentration of new economies (e.g. information technology, advanced technology, innovative design of architecture, art, fashion, culture, graphic arts, etc.) in certain inner city areas and the creation of clusters of new economies and new entrepreneurial epicentres in inner city areas. The paper provides examples of such clusters and epicentres in metropolitan cities located in both the economic core and the periphery of Europe, such as Milan, Barcelona and Athens.

\section{The change of urban morphology in the contemporary cities}

The development of new technologies in the sectors of both architectural design and construction techniques contributed to avant-garde architecture and distinct urban morphology, which are selected more and more often in strategic planning and renewal of cities. The contemporary computer-aided architectural design software has already escaped from the stage of a simple presentation. We can compose directly and create a whole project by means of this new software. Without this software, it is almost certain that this avant-garde architecture could not be produced. Even if we had the suitable modern materials (such as titanic zinc, membranes of ethylene etc) these architectural structures could not be constructed, without the corresponding static calculations of the suitable static software.

However, the innovative formations that result in the cities come in contradiction with the traditional and historical forms of them. This reinforces the problem of a "place identity" in this age of economic and cultural globalisation. More and more researchers - urbanists, architects, sociologists, economists etc, are getting involved with the future of cities. The city of today is presented as an entity with intense complexity. As a reaction against the tendencies of suburban sprawl and the individualisation, which dominates all the events of contemporary life, the urban centres and the public space become critical expressions of local life. Their recapture and regeneration acquire particular importance in contemporary cities [1-3].

The architecture and the urban planning are called to play their own dynamic role, in order for the cities to meet the challenges of international competition. They constitute important critical tools for the development of metropolitan areas and they contribute to the creation of particular advantage urban landscape and the creation of symbolism and an image of glamour [4]. The important urban projects of integrated interventions and innovative design were usually results of the high economic development of the cities. However, in the age of globalisation, the terms have been reversed and urban planning is used as a tool 
for the economic boost of cities in the new competitive environment [4-6]. We can claim that the urban planning and the innovative architectural design can be used as tools to produce or to contribute to the socio-economic development [6, 7].

In order for the cities to meet the new challenges, buildings are designed, which are immediately connected with the new technological achievements. The main concern of all cities is to hold international events (international expositions, international cultural forum, Olympic Games etc) and get international fame through them. This can be accomplished by promoting the buildings and urban reformations that are designed for these events. They are trying to create an attractive city. The objective is to create a city symbol and attract the largest number of visitors. For this reason, architectural solutions and urban interventions, whose characteristic is innovation and originality, are usually selected. There is a tendency in all cities to accumulate buildings designed by famous architects in their building potential.

In the metropolitan area of Milan, there are innovative architectural forms at various sites, such as: the new Rho-Pero pole of Milan exposition designed by the famous architect Massimiliano Fuksas [8, 9] and innovative architectural forms of the CityLife project that was designed by Zaha Hadid, Arata Isozaki, Daniel Libeskind e Pier Paolo Maggiora (fig. 1) [10].

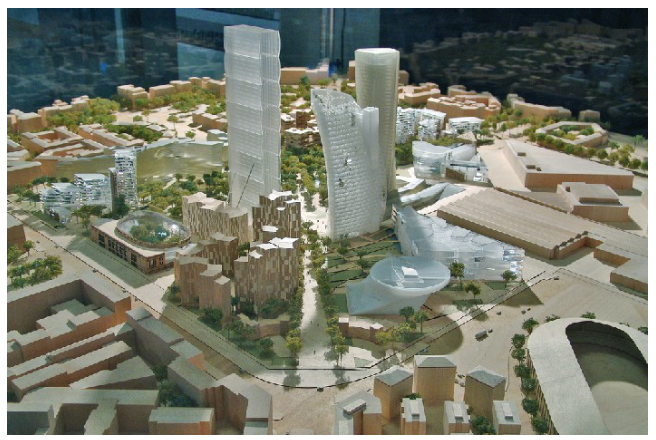

Figure 1: Milan, CityLife project, arch. Zaha Hadid, Arata Isozaki, Daniel Libeskind e Pier Paolo Maggiora.

In Athens, during the Olympic Games 2004 the image of the city in general was improved even if there were not many buildings of innovative morphology. They mainly concerned sport facilities, such as: the Olympic Athletic Center of Athens (OAKA) and other public open spaces in the surrounding area, designed by the architect Santiago Calatrava (fig. 2) and the pedestrian bridge at Katehaki avenue designed also by the same architect. The famous architect, Bernard Tschumi, also worked in Athens. He had won the project of the New Acropolis Museum in an international competition.

Barcelona, on the other hand, assembles modern buildings and urban open spaces designed by famous architects, such as the Park "Diagonal del Mar" designed by Eric Mirages, the "Fish" building at Barcelona beach designed by 
Frank O'Gehry, the Agbar Tower designed by Jean Nouvel and the Telecommunications Tower on Montjuic hill designed by Santiago Calatrava. Also projects such as the Cinema Building at the Plaça de las Arts by Zaha Hadid and the new Camp Nou Stadium of FC Barcelona by Norman Foster are designed.

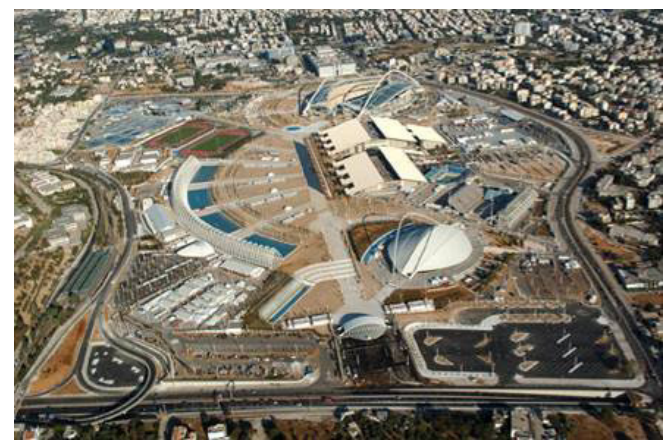

Figure 2: Olympic stage of Athens and other public open spaces in the area around, arch. Santiago Calatrava.

Over the last years, we have observed an essential rebirth of the importance of architecture and urban planning. They are called to incorporate the innovative architectural forms into the urban area. In certain cases, they have had a direct impact by reviving cities and areas, not only at the cultural but also at the economic level. It is certain that the architecture on its own cannot change the operation or the image of an entire city or of a whole metropolitan area. This requires political will, as well as strategic and regional planning.

The most important challenge for the urban planning in the present informative period is to restore the culture of cities. This can be achieved by means of urban planning and planning of public spaces. The public space could be the factor of balance in the city in front of the private commercial centres as spaces of sociability. The way of use and operation of public space is decisive for the development and the regeneration of a city. The recapture and restructuring of public space in the city, aiming to its operation as a space of social cohesion and social exchanges, can make the city create culture, sociability, communication, and support the democracy. In this way the city can oppose to the urban crisis that is characterized by dissolution, chopping, and privatisation $[2,3]$.

An example of successful urban planning is the metropolitan area of Barcelona. The reclaim of public space is apparent in the entire metropolitan area, focusing on the regions of the working class in particular; these regions need much more attention on the social-spatial regeneration. A network of public open spaces has been designed in Barcelona. This network consists of parks, small squares in the historical city, pedestrian streets and even open public spaces in front of libraries and museums, where social life and important architectural forms are assembled. However, what can be considered as a 
particular success is the spontaneity of uses, the density of interaction, the freedom of expression, the multi-functionality of the space and the multiculturalism of the life at the streets that is caused with the tolerance of informal trade and other informal events [3].

\section{Territorial transformations and extension of CBD in the post industrial cities}

The new terms of globalized economy have caused a hard competition among the urban centres all over the world. They try to attract investors, visitors and residents. The capital of new type investments is flexible and can be traced in any place. Because of this, all the cities have become potential receptors. Most of them have begun a city marketing process. They advertise it on the Web as a place of tourist destination and as an investments receptor, elevating and advertising its advantages [11].

In the post-modern city, territorial transformations are observed that can be categorized in two groups: a. in the urban epicentres that are located in the inner city and b. in the fragment urbanity that is diffused around of the city or it is located in specific regions out of the city $[12,13]$. As urban epicentres we can define a planned urban area, which is characterised of open public space and density of buildings. These urban clusters can be distinguished according to the use, the planning and their arrangement, in several categories [12]. In this article we will focus on the emerging of new clusters of technology-intensive and knowledge- based firms in inner city areas.

These clusters constitute urban islands, which are located in the inner city and are part of the CBD (Central Business District) area. This core consists of technology-intensive firms and knowledge-based firms and institutions, which offer high level services. Furthermore, they involve supplementary uses and activities, as housing commercial shops that promote the fashion and expensive restaurants. Their planning is usually characterized of innovative architectural design and distinct urban morphology. They represent parts of the city that have resulted by the redevelopment of old industrial areas and other installations, which had been abandoned and have no reason, anymore, to be situated at the core of the city. They usually act as autonomous cores. They constitute centres of symbolic character and economic supremacy [12].

The post-industrial trajectory of each city can be different from another one. For example, it could specialise its growth and head towards a specialised new economic sector, such as new media, new technologies of communication, ICT sector (information and communication technology) or boost the design and fashion sectors. However, there are still some common attributes concerning the creation of clusters and the territorial transformations of cities [14].

There have been theories that support the dissolution of the necessity for the existence of clusters of similar economies, because of the networks technology development and the devaluation of the face-to-face contact [14, 15]. However, we have realised precisely the opposite conclusion so far. There are certain factors that boost and establish the necessity to concentrate similar activities, the 
necessity of socialization of individuals and the importance of interpersonal relations. For example, within the sector of intensive technologies, the distribution of knowledge and leisure activities, it seems that the firms prefer to concentrate on the inner city because of specific factors. Such factors could be the networking, the collaboration concerning several practices of learning, research and innovation, the creation of specialised human resources staff who could have the possibility to move from one firm to another, the access to specialised instruments etc $[14,16]$.

Exploring further the new subjects of urban theory, we realise that teleworking (people who work exclusively on-line at home) is not yet a fact [3, 17]. A lot of people work part time on-line at home. Nevertheless, most of them continue to belong to a working environment and move in the inner city. The development of technology (such as mobile telephony, broadband internet, wireless network, etc) gives them the possibility of working and still being connected in the network of professional collaborators, suppliers, and clients even if somebody is on the move. This actually represents a new territorial dimension of work and the activities in general of a person since he has the possibility to move and yet maintain his electronic connections. He maintains the flows while he moves in the space $[3,18]$.

The above statement is enforced by the creation of new cores in the inner cities, leading in this way to the multicentre cities. The spaces occupied by these new urban centres, are mainly former abandoned industrial regions or regions of activities that have lost their old glamour, for example the space of international Fair of Milan (fig. 1) the restructuring of which was the prize of an international architectural competition. These new urban centres consist of multilevel buildings of offices, quarters of residences addressed to high income classes, entertainment and consumption facilities, open urban spaces of green and in general public spaces of high aesthetic and quality. These areas wish to become the new reference centres in contemporary cities. They constitute samples of avant-garde architecture and distinct urban morphology. Also, a new core of activities has been designed in Milan, "the city of fashion", near the train station of Porta Garibaldi [19]. It will involve a museum, a faculty of fashion and a multilevel building, the "tower of fashion", designed by the architect Cesar Pelli, a park and an exhibition kiosk. In addition, a complex of buildings will be constructed to accommodate the services of Lombardy Region, multilevel buildings of offices and the new multilevel Town Hall of Milan. The set of interventions constitutes the Varesine project and is designed by the architects Pei Cobb Freed and Partners and Cesar Pelli.

In the city of Milan, the ICT firms are located in the northeast zone, creating an epicentre of new technologies in the city [20]. In Milan, two companies that involve the development of North Milan, the Agenzia di Sviluppo Nord Milano (ASNM) and the Agintec operate with success. They organize the public and private actions and investments promoting the development of ICT. The ASNM seeks to recreate the northern zone of Milan, where companies related to the new digital technologies have been installed over the last years. In the aspect of history, the region has been characterized by the concentration of big industrial 
enterprises. The ASNM plans and forecasts the re-using and the redefinition of the zone. It aims to create new working places and infrastructures for research, tech transfer and training centres, provide advanced services to enterprises and promote the activities and services in the sector of multimedia and information technology. It also plans the restructuring of urban space by creating upgraded environment consisted of green spaces, infrastructures and networks aiming to attract new companies and centres that involve the innovative technologies [21].

As a characteristic example of areas planning through the creation of epicentres, we can note the "22@ Barcelona project" that was planned in 2005. It concerns the renovation of Poblenou, which is the old industrial zone in Barcelona. The project forecasts the creation of epicentres through the installation of tech transfer and research centres in that zone. It involves a zone of 300 hectares and it forecasts the demolition of some buildings, the maintenance of some others, which present more architectonical or historical interest, the construction of new building complexes and the planning of open public spaces. The fundamental objective of the project 22@ is the creation of contemporary network installations and the connection with successful urban interventions on the reformation of Barcelona beach, the FORUM of cultures and other avant-garde or interesting buildings in the wider area. Such interventions seek to attract private enterprises and commercial activities permanently in the area apart from the already planned tech transfer, research and training centres (ICT, media) (fig. 3). The construction of subsidised housing, open public spaces, cultural and social infrastructures are also forecasted. This intervention aims to create an upgraded quality living and working environment. It also ensures that all the residents and visitors to Barcelona will use the infrastructures and the open public spaces without excluding any social group [22].

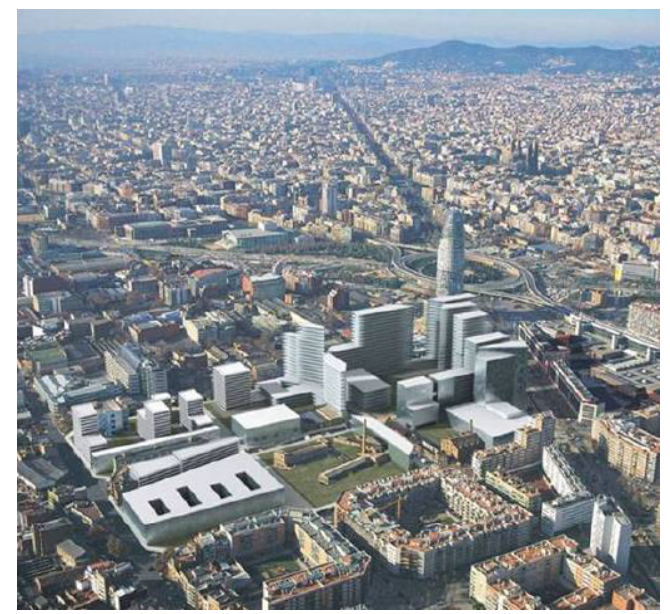

Figure 3: $\quad$ The Barcelona 22@ project, ICT-media centres.

Clusters of similar economic activities that concern the new technologies of information and communication are also located in Athens. The big difference 
between the upper two examples is that the clusters in Athens resulted spontaneously without any strategic planning by government institutions. These clusters are located in the region of Marousi and recently in the region of Kanza, where there are concentrations of similar enterprises related to telecommunications, information technology and media. The buildings that house them are contemporary but they do not present any avant-garde architecture.

Both the role and the influence of political choices regarding the shaping, the growth and the management of new economies clusters are very important [14, 16]. Most of these clusters result under the private initiative almost spontaneously (or following a market research in order for the enterprises to be profitable), without the appropriate planning by government institutions. This includes various risks, such as: 1 . the creation of peculiar urban hubs which function only in concrete hours of a day or night, 2. the breakdown of social cohesion (for example within the clusters of culture and high art) and 3. the possible future degradation of the area (within the clusters of nightlife amusement facilities). The local authorities and the strategic planning can play a serious role in the functional dimension of these clusters and in the process of redevelopment of a region $[13,14]$.

\section{Conclusions}

The cities are transformed in the aspect of morphology and space, as well as socially and economically. Regarding the urban structure, there is an obvious tendency to create epicentres within the inner city. If we compare the cities of Milan, Barcelona and Athens, we will observe that all of them seek to create epicentres of economic force (or to enforce the existing ones) through the concentration and the attraction of similar economic activities of high Technology and know-how, (companies of information technology and telecommunications) and creative activities in connection with the new technologies (design companies - architectural design, fashion design, graphic design, publications, multimedia).

The architecture and the urban planning are called to play an important role in the regeneration of public spaces in new metropolis. The cities take part in the international competition to become attracting destinations for the population, no necessarily for residents, but for the visitors and investors. They try to strength their position seeking and encouraging the creation of innovative urban spaces and avant-garde architecture.

The development of new technologies in both architectural design and construction techniques sectors has contributed to avant-garde architecture and distinct urban morphology. Without this new technology of planning by means of computer (software of architectural planning, static resolution, 3D animation, photorealism, etc) and the new constructional materials, it is more likely that the new built forms would not be so innovative. It has also contributed considerably to the maximisation of territorial scope in the work of international architects. Nowadays, famous architects design anywhere in the world. 
To sum up, we can mention the following conclusions:

1. The architecture-urban planning and the construction techniques arising from the use of new technologies have obvious results in the space, such as: 1.1. the emergence of innovative morphology epicentres that lend a particular and modern global character to the city; 1.2. the creation of buildings as symbols in the inner city and at the entrances of the city as well as innovative urban interventions that lend particular prestige; 1.3. the reinforcement of the city position in the international competition; 1.4. the creation of international architectural tendency that is represented mainly by architects of international fame; 1.5. the creation of "international" buildings that can be established in any city without necessarily keeping the local character of the place; and 1.6. the change in the spatial-economic structure of the city.

2. The territorial concentrations of similar economic activities of high technology and know-how (companies of information technology and telecommunications) and creative activities in connection with the new technologies (design companies - architectural design, fashion design, graphic design, publications, multimedia) have both led to 2.1. the creation of epicentres of new economic activities that attribute a contemporary international character to the city; 2.2. the creation of new urban cores within the city having as a result the multi-centres cities; 2.3. enforcing the city position in the international competition; 2.4. the creation of sovereign epicentres of operational force where enterprises of international scope are assembled and lend a particular character of prestige and economic growth to the city; 2.5. the change in the spatial-economic structure of the city; 2.6. the creation of buildings as symbols in the inner city (such as museums of arts, science and technology, public buildings of services, private buildings of offices etc); 2.7. the creation of contemporary network installations in order to serve these territorial concentrations; and 2.8. the exclusion of several social groups of low income and some individuals who are not specialised in the use of new technologies.

\section{References}

[1] Hall, P. (1998), Cities In Civilization, New York: Pantheon

[2] Borjia, J. with Zaida, M. (2001), L'Espai Public: Ciutat I Ciutadania, Barcelona: Diputacio de Barcelona

[3] Castells, M. (2001), 'Space of Flows, Space of Places: Materials for a Theory of Urbanism in the Information Age'

[4] Gospodini, A. (2000), European Cities In Competition And The New 'Uses' Of Urban Design; a challenge for the Greek cities', a paper presented in the International AESOP Congress, Brno, Czech Republic, 1823 July 2000 and The Journal of Urban Design, 2002, 7(1) pp. 59-74

[5] Gospodini, A. (2002), 'European Cities and Place Identity'. Discussion Papers Series, 8(2) pp.19-36, Volos: University of Thessaly Publications. Also a web publication at www.prd.uth.gr/research/DP/2002/uth-prd-dp2002-02_en.pdf 
[6] Cuthbert, A. (2006), 'Urban Design and Spatial Political Economy Review and Critique of the last 50 years' in Cuthbert, A. (edit) The Form Of Cities, Oxford: Blackwell, 2006, pp.1-60. Also a web publication at http://www.fbe.unsw.edu.au/staff/alexander.cuthbert/publications.asp

[7] Inam, A. (2002), 'Meaningful urban design - teleological, catalytic, relevant', in Journal of Urban Design. 7(1) pp.35-58

[8] Archimagazine, http://www.archimagazine.com/apolo.htm

[9] The new Milan- Based Exhibition System, www.nuovopolofieramilano.it

[10] CityLife project, http://www.city-life.it

[11] Kavaratzis, M. (2007), 'City Marketing: The Past, the Present and Some Unresolved Issues' in Geography Compass, Vol. 1(3), pp. 695-712

[12] Gospodini, A. (2005), 'Portraying, Classifying and Understanding the emerging New Landscapes in the Postmodern City', in Cities, Vol. 23(5), pp.311-331

[13] Gospodini, A. (2006), 'Sketching out, interpreting and categorizing the new landscapes of post-industrial city', in Gospodini, A. and Mperiatos, E. (edit) New Urban Landscapes And Greek City, Athens: Publications Criticism, 2006, pp.26-50 (in Greek)

[14] Gospodini, A. ((forthcoming), 'Post-industrial trajectories of Mediterranean European cities. Learning from post-Olympics Athens and the Greek experience'

[15] Cairncross, F. (1998), The Death Of Distance. How The Communications Revolution Will Change Our Lives, Boston: Harvard Business School Press

[16] Pratt, A. (2000), 'New media, the new economy and new spaces', in Geoforum Vol. 31, pp. 425-436

[17] Gillespie, A. and Richardson, R. (2000), 'Teleworking and the city: myths of workplace transcendence and travel reduction', in J. Wheeler, Y. Aoyama and B. Warf (eds), Cities In The Telecommunications Age: The Fracturing Of Geographies, London: Routledge, pp.228-248

[18] Kopomaa, T. (2000), The City In Your Pocket: Birth Of The Mobile Information Society, Helsinki: Gaudemus

[19] Skyscrapercity web forum, http://www.skyscrapercity.com

[20] Capello, R. (1999), 'Spatial transfer of knowledge in high technology milieux: learning versus collective learning processes', in Regional Studies, Vol. 33(4) pp. 353-365

[21] Albolino, S., Aniello, V., Catino, M., Fuchs, G., Garnsey, E., Le Gales, P and Perulli, P. 'The institutions of net economy' Institute of search participation on the organizational systems (edit) a web publication at www.mi.camcom.it/upload/file/263 (in Italian)

[22] What is 22@ Barcelona? The innovation district, www. bcn. es / 22@bcn 